\title{
Penerapan Model Make a Match Berbasis Saintifik untuk Meningkatkan Hasil Belajar Tematik Siswa
}

\author{
Erfina Yuliana $^{1}$, Yari Dwikurnaningsih ${ }^{2}$ \\ ${ }^{1,2}$ Program Studi Pendidikan Profesi Guru PGSD Fakultas Ilmu Pendidikan UKSW Salatiga \\ 1erfinayul@gmail.com \\ 2yari.dwikurnaningsih@staff.uksw.edu
}

\begin{abstract}
ABSTRAK
Penelitian ini bertujuan untuk meningkatkan hasil belajar tematik siswa kelas IV SDN Kutowinangun 11 melalui penerapan model pembelajaran Make a Match berbasis pendekatan saintifik. Jenis penelitian yang digunakan adalah penelitian tindakan kelas model Stringer yang mencakup tahap look, think, dan act. Instrumen pengumpulan data menggunakan tes formatif, lembar observasi, dan catatan lapangan. Teknik analisis data berupa deskriptif komparatif dengan subjek penelitian adalah siswa kelas IV SDN Kutowinangun 11. Hasil penelitian menunjukkan adanya peningkatan persentase aktivitas belajar siswa sebesar 79\% pada siklus I dan meningkat menjadi $85 \%$ pada siklus II. Peningkataan aktivitas siswa berdampak pada ketuntasan hasil belajar tematik yang ditunjukkan pada siklus I sebesar $72 \%$, dan meningkat menjadi $83 \%$ pada siklus II. Berdasarkan hasil penelitian tersebut, model pembelajaran Make a Match berbasis saintifik dapat meningkatkan hasil belajar tematik siswa.
\end{abstract}

Kata kunci: Make a match, Saintifik, Hasil belajar tematik

\section{ABSTRACT}

This study aims to improve the thematic learning outcomes of fourth grade students of SDN Kutowinangun 11 through the application of the Make a Match learning model based on the scientific approach. The type of research used is Stringer class action research which includes the look, think, and act stages. The instrument of data collection uses formative tests, observation sheets, and field notes. Data analysis techniques in the form of descriptive comparative with the research subjects were fourth grade students of SDN Kutowinangun 11. The results of the study showed an increase in the percentage of student learning activities by $79 \%$ in the first cycle and increased to $85 \%$ in the second cycle. Reinforcement of student activities has an impact on the completeness of thematic learning outcomes shown in the first cycle of $72 \%$, and increased to $83 \%$ in cycle II. Based on the results of these studies, the Make-Match learning model based on scientific research can improve students' thematic learning outcomes.

Keywords: Make a match, Scientific, Thematic learning results

\section{PENDAHULUAN}

Kurikulum yang diterapkan pada tingkat pendidikan sekolah dasar saat ini adalah Kurikulum 2013 yang berbasis kompetensi, menggunakan pendekatan saintifik dengan mengembangkan sikap, keterampilan, dan pengetahuan siswa. Penerapan Kurikulum 2013 menggunakan pembelajaran tematik, melalui model pembelajaran yang mengaitkan beberapa muatan pelajaran menggunakan tema tertentu sehingga siswa mendapatkan pengalaman belajar yang bermakna. Min, dkk (2012: 273) menyatakan pembelajaran tematik adalah salah satu strategi pembelajaran yang menggunakan tema-tema untuk menciptakan pembelajaran yang aktif, menarik, dan bermakna. Sedangkan menurut Webb dan Pearson (2012), model tematik merupakan kesatuan tema-tema yang memuat gagasan pengajaran dan mengintegrasikan beberapa topik. Pembelajaran tematik akan membuat pembelajaran lebih menarik dan bermakna bagi siswa karena menyajikan tema-tema pembelajaran yang aktual dan kontekstual dalam kehidupan sehari-hari (Sari, dkk, 2017: 110).

Karakteristik pembelajaran tematik antara lain berpusat pada siswa, memberikan 
pengalaman langsung, pemisahan muatan pembelajaran tidak terlalu jelas, menyajikan konsep dari beberapa mata pelajaran, bersifat fleksibel, hasil belajar sesuai minat dan kebutuhan siswa, serta menggunakan prinsip belajar sambil bermain yang menyenangkan (Rusman, 2014: 258). Pembelajaran tematik menekankan penerapan konsep belajar sambil melakukan sesuatu, sehingga guru perlu merancang pembelajaran yang memberikan pengalaman belajar serta berpengaruh pada aktivitas dan hasil belajar siswa. Menurut Nahdiyatin (2016: 84), hasil belajar adalah cerminan keberhasilan atau pencapaian tujuan dari proses pembelajaran yang telah terlaksana dan diakhiri dengan suatu evaluasi.

Pembelajaran tematik yang diterapkan juga harus memiliki kebulatan sehingga dari beberapa muatan yang ada dalam tema tertentu dapat diterima oleh siswa secara utuh. Hal ini dapat teratasi dengan kreativitas guru dalam mendesain pembelajaran. Guru perlu mengembangkan dan memperbaharui model pembelajaran agar memberikan suasana belajar yang berbeda dari sebelumnya dan membuat hasil belajar siswa meningkat (Aprilia, dkk, 2018). Pembelajaran tematik dalam Kurikulum 2013 harus didesain semenarik mungkin dan sedekat mungkin dengan lingkungan siswa agar tercipta suasana belajar yang menyenangkan sehingga dapat membangkitkan semangat siswa dalam menggali informasi dari materi yang akan dipelajari. Hal tersebut serupa dengan pendapat dari Trianto (2011: 26) yang menjelaskan bahwa proses pembelajaran yang aktif, efektif, inovatif, kreatif dan menyenangkan dapat dilaksanakan siswa yang disiapkan oleh guru melalui kegiatan-kegiatan yang menarik, menyenangkan untuk membangkitkan rasa ingin tahu, memotivasi siswa untuk berpikir kritis, dan menemukan hal-hal baru.

Mengacu pada pelaksanaan Kurikulum 2013, SDN Kutowinangun 11 sudah berusaha melaksanakan pembelajaran yang sesuai dengan tuntutan kurikulum. Hal tersebut relevan dengan visi sekolah yaitu "terwujudnya sekolah berkualitas, berakhlak mulia, dan peduli lingkungan". Didukung dengang misi pertama sekolah yaitu "melaksanakan pembelajaran aktif, inovatif, kreatif, efektif, dan menyenangkan". Visi dan misi ini berusaha dicapai oleh guru kelas IV SDN Kutowinangun 11 dengan berusaha menggunakan berbagai strategi dan model pembelajaran.
Berdasarkan hasil refleksi bersama guru kelas IV SDN Kutowinangun 11 dapat diidentifikasi beberapa permasalahan sebagai berikut: (1) guru belum sepenuhnya menerapkan model pembelajaran yang bervariasi, (2) keterlibatan siswa kurang diperhatikan oleh guru, (3) pembelajaran cenderung mengacu pada Buku Guru dan Buku Siswa meskipun terkadang tidak sesuai, (4) kesulitan memadukan antar muatan pelajaran dalam pembelajaran tematik, dan (5) siswa cenderung memperoleh materi dari aktivitas membaca dan mendengar belum sampai aktivitas melakukan. Hal tersebut berdampak pada perolehan hasil belajar Penilaian Akhir Semester 1 siswa yang masih ada di bawah Kriteria Ketuntasan Minimal (KKM), yaitu pada muatan Bahasa Indonesia dari 18 siswa, hanya 8 siswa $(44,4 \%)$ yang tuntas dan pada muatan IPA hanya 6 siswa $(33,3 \%)$ yang tuntas.

Menindaklanjuti permasalahan tersebut, peneliti bersama tim kolaborator merasa permasalahan tersebut termasuk permasalahan yang perlu dan penting untuk dipecahkan. Peneliti dalam hal ini akan menggunakan rancangan pembelajaran tematik dengan model Make a Match berbasis pendekatan saintifik. Penerapan model Make a Match berbasis saintifik ini diharapkan membuat siswa lebih aktif dalam pembelajaran sehingga hasil belajar tematik siswa dapat lebih maksimal. Huda (2013: 253) menyatakan bahwa model Make a Match dapat meningkatkan aktivitas belajar siswa, baik secara kognitif maupun fisik karena terdapat unsur permainan dan menjadikan model ini menyenangkan. Model Make a Match juga memberi kesempatan siswa untuk saling bekerja sama dengan orang lain (Lie, 2010).

Pembelajaran model Make a Match melibatkan siswa sepenuhnya karena guru disini berlaku sebagai pembimbing jalannya diskusi dalam mencocokkan jawaban siswa. Keterlibatan siswa terlihat dari bagaimana usaha siswa dalam mencari pasangan kartu jawaban yang sesuai dengan kartu pertanyaan. Keterlibatan siswa dalam model Make a Match dapat dikatakan sebagai pengalaman belajar siswa itu sendiri. Pengalaman belajar merupakan upaya siswa untuk terus berkembang dan memperluas pengetahuannya.

Penelitian yang dilakukan Wibowo dan Marzuki (2015) menyatakan model Make a Match dapat meningkatkan motivasi dan hasil belajar IPS, ditunjukkan dengan motivasi belajar siswa meningkat dari 75,91 pada siklus 
I menjadi 78,17 pada siklus II. Sementara itu, hasil belajar siswa meningkat ditunjukkan dengan persentase ketuntasan belajar 52,17\% pada siklus 1 dan pada siklus II meningkat menjadi $86,96 \%$. Penelitian lainnya yaitu oleh Rusminawati dan Mediatati (2017) yang menyatakan hal serupa, bahwa penerapan model Make a Match dapat meningkatkan hasil belajar IPS siswa kelas 4 SD. Berdasarkan hasil penelitian tersebut, pada siklus I sebanyak 7 siswa tidak tuntas $(29 \%)$ dan 17 siswa tuntas (71\%), sedangkan pada siklus II didapatkan sebanyak 22 siswa tuntas (92\%) dan 2 siswa tidak tuntas (8\%).

Berdasarkan ulasan latar belakang tersebut, peneliti melakukan penelitian tindakan kelas dengan judul "Penerapan Model Make a Match Berbasis Saintifik untuk Meningkatkan Hasil Belajar Tematik Siswa".

\section{METODE PENELITIAN}

Penelitian ini menggunakan metode penelitian tindakan kelas. Menurut Arikunto (2009: 3), penelitian tindakan kelas adalah pencermatan kegiatan belajar dengan tindakan sengaja dimunculkan dan terjadi dalam kelas secara bersama. Penelitian tindakan kelas merupakan upaya untuk memperbaiki proses pembelajaran atau memecahkan masalah yang dihadapi dalam pembelajaran (Mulyasa, 2015: 34). Penelitian tindakan kelas ini menggunakan desain penelitian model stringer (Yaumi, 2014: 45).

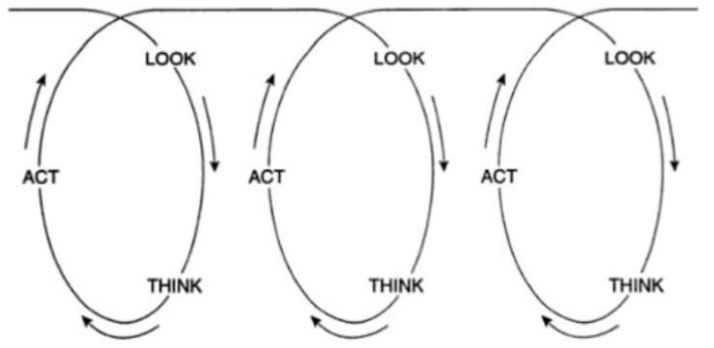

Gambar 1. Model Stringer dalam Penelitian Tindakan Kelas

Penelitian ini terdiri dari dua siklus. Berdasarkan gambar, setiap siklus terdapat tiga tindakan yaitu: observasi (look), pemecahan masalah (think), dan tindakan (act). Pelaksanaan pada setiap siklus dilakukan sesuai dengan indikator yang telah ditentukan. Pelaksanaan siklus I dilakukan dengan beberapa tindakan yang meliputi observasi (look), pemecahan masalah (think), dan tindakan (act). Hasil dari refleksi siklus I dijadikan dasar dalam penyusunan rencana kegiatan pada siklus II dengan tindakan yang sama seperti siklus I. Jika pada siklus II tidak ditemukan permasalahan maka penelitian tindakan kelas yang dilakukan dianggap berhasil.

Penelitian ini dilaksanakan di SD

Negeri Kutowinangun 11 Kota Salatiga. Subjek penelitian adalah siswa kelas IV SD Negeri Kutowinangun 11 yang berjumlah 18 siswa, terdiri dari 14 siswa laki-laki dan 4 siswa perempuan. Penelitian dilakukan pada semester II tahun pelajaran 2018/2019. Variabel dalam penelitian ini dibedakan menjadi dua, yaitu variabel bebas yang berupa penerapan model Make a Match berbasis saintifik, dan variabel terikat berupa hasil belajar tematik.

Penelitian ini menggunakan teknik pengumpulan data tes dan non tes. Teknik tes digunakan untuk memperoleh hasil belajar tematik berupa pemberian soal, sedangkan non tes yang berupa dokumentasi, observasi dan catatan lapangan digunakan untuk memperoleh data aktivitas pada pelaksanaan tindakan dengan menggunakan model Make a Match berbasis saintifik. Teknik analisis data kuantitatif berupa deskriptif komparatif, yaitu dengan menghitung persentase ketuntasan hasil belajar siswa pada siklus I kemudian dibandingkan dengan persentase ketuntasan hasil belajar siswa pada siklus II. Penilaian tindakan kelas ini dikatakan berhasil apabila hasil belajar siswa mencapai ketuntasan yang ditentukan, yaitu $65 \%$. Sedangkan teknik analisis data kualitatif berupa analisis deskriptif berdasarkan hasil dari aktivitas siswa dalam pembelajaran.

\section{HASIL \& PEMBAHASAN}

Hasil penelitian yang dilakukan pada siklus I dan siklus II dikelas IV Sekolah Dasar menunjukkan adanya peningkatan hasil belajar dengan menerapkan model pembelajaran Make a Match. Hasil belajar peserta didik mengalami peningkatan dari siklus I ke siklus II. Peningkatan tersebut dapat dilihat pada tabel 1 . 
Tabel 1 Peningkatan Hasil Belajar Peserta Didik Kelas III

\begin{tabular}{clcccc}
\hline & & \multicolumn{3}{c}{ Siklus I } & \multicolumn{2}{c}{ Siklus II } \\
\cline { 3 - 6 } No & Kategori & & & & \\
\cline { 3 - 6 } & & Jumlah & Persentase (\%) & Jumlah & Persentase (\%) \\
\hline 1 & Siswa tuntas & 13 & 72 & 15 & \\
\hline 2 & Siswa belum tuntas & 5 & 28 & 3 & 17 \\
\hline 3 & Jumlah & 18 & 100 & 18 & 100 \\
\hline 4 & Rata-rata & 80 & - & 84 & - \\
\hline
\end{tabular}

Tabel I menunjukkan perbandingan ketuntasan hasil belajar tematik, dapat diketahui bahwa terdapat peningkatan hasil belajar dari siklus I ke siklusII. Pada pelaksanaan siklus I terlihat peningkatan jumlah peserta didik yang tuntas sebanyak 13 peserta didik dengan persentase tuntas $72 \%$, sedangkan 5 peserta didik lainnya masih memperoleh nilai di bawah Kriteria Ketuntasan Minimum (KKM) dengan persentase $72 \%$. Perolehan rata-rata hasil belajar pada siklus I yaitu 80 .

Selanjutnya tindakan dilanjutkan dengan pelaksanaan tindakan siklus II. Hasil pelaksanaan tindakan di siklus II menunjukkan bahwa sebanyak 18 peserta didik memperoleh nilai di atas KKM >65 dengan persentase $83 \%$, nilai rata-rata hasil belajar pada siklus II mencapai 84. Dari hasil belajar tematik dan ketuntasan belajar peserta didik siklus II tersebut dapat diketahui bahwa indikator keberhasilan tindakan penelitian telah tercapai.

Berdasarkan data tersebut, hasil belajar tematik yang dilihat dari nilai rata-rata dan persentase ketuntasan belajar klasikal dari penerapan model Make a Match berbasis saintifik sudah berhasil. Hal ini sejalan dengan penelitian pembelajaran selama penelitian, aktivitas siswa mengalami peningkatan dari $79 \%$ pada siklus I (kategori baik) meningkat menjadi $85 \%$ pada siklus II (kategori sangat baik). Hal tersebut menunjukkan bahwa penerapan sintak model Make a Match berbasis saintifik selama pembelajaran mendapat hasil yang signifikan terhadap keaktifan siswa. Peningkatan aktivitas tersebut sebagai hasil dari tugas-tugas yang dilakukan selama pembelajaran. Hal ini serupa dengan yang dijabarkan Zahroul dan Nur (2015) yang menyatakan siswa berperan aktif dalam kegiatan pembelajaran, bekerja sama untuk mencari tahu jawaban dari soal yang diberikan, serta semangat siswa meningkat karena keterlibatannya dalam kegiatan pembelajaran. Hal tersebut akan mempengaruhi hasil belajar yang dicapai siswa. Selain itu, pembelajaran model Make a Match ini tidak hanya sekedar menerima materi yang disampaikan oleh guru, melainkan siswa dapat belajar dan berdiskusi dengan siswa yang lain.

Melalui kegiatan bermain kartu, siswa mencari pasangan kartu pertanyaan dan jawaban dengan percaya diri. Guru memberikan apresiasi, tanggapan dan merevisi apabila ada konsep yang kurang tepat. Pelaksanaan langkah-langkah model Make a Match berbasis saintifik selama pembelajaran sudah cukup baik, hanya saja ada fase pendekatan saintifik yang belum muncul yaitu pada fase menalar dikarenakan karakteristik siswa kelas I yang belum mampu untuk melakukan penalaran dengan baik. Pemberian motivasi juga sangat mempengaruhi semangat siswa dalam proses pembelajaran, sehingga pada siklus II pemberian motivasi dan semangat lebih ditingkatkan.

Ketuntasan hasil belajar pada muatan Bahasa Indonesia dan IPA menunjukkan masih ada beberapa siswa yang belum mencapai ketuntasan. Hal ini dikarenakan, soal yang dikerjakan membutuhkan ketelitian dalam mengerjakan, sehingga berdampak pada hasil yang didapatkan. Berdasarkan perolehan hasil belajar pada siklus I menunjukkan hasil belajar tematik belum mencapai indikator yang sudah ditentukan (look). Terlihat dari perolehan hasil belajar tematik pada setiap muatan pelajaran yang masih belum mencapai indikator yang ditentukan. Oleh karena itu, perlu upaya perbaikan untuk mencapai indikator dengan dilakukannya tindakan pada siklus II. Berdasarkan hal tersebut, peneliti melakukan 


\section{KESIMPULAN \& SARAN}

Berdasarkan penelitian yang telah dilaksanakan, dapat disimpulkan bahwa penerapan model Make a Match berbasis saintifik dapat meningkatkah hasil belajar tematik siswa di kelas IV Sekolah Dasar. Peningkatan tersebut ditunjukkan oleh: 1) persentase ketuntasan peningkatan hasil belajar peserta didik pada siklus I $72 \%$ menjadi $83 \%$ di siklus II sehingga terjadi peningkatan sebesar $11 \%$.

Berdasarkan simpulan di atas, maka diajukan saran sebagai berikut:

1. Kepala sekolah hendaknya selalu memberikan pembinaan dan pengawasan mengenai peningkatan kompetensi guru dalam menerapkan model-model pembelajaran, salah satunya model Make a Match berbasis saintifik agar pembelajaran peserta didik bisa lebih bermakna.

2. Guru hendaknya selalu memfasilitasi peserta didik agar ikut terlibat aktif dalam pembelajaran secara langsung sehingga pengalaman peserta didik terbentuk dan mudah dalam belajar tematik.

3. Bagi peneliti, hendaknya hasil penelitian ini dapat dijadikan pedoman jika akan melakukan penelitian yang sejenis, dengan memperbaiki kelemahankelamahan di penelitian mendatang.

\section{DAFTAR PUSTAKA}

Aprilia, L.A., Slameto, \& Radia, E.H. (2018). Meningkatkan Hasil Belajar PPKn Melalui Model Pembelajaran Numbered Heads Together Berbasis Kurikulum 2013. Wacana Akademika, 2(1), 85-98.

Arikunto, Suharsimi. (2015). Dasar-dasar Evaluasi Pendidikan Edisi 2. Jakarta: Bumi Aksara.

Huda, Miftahul. (2013). Model-Model Pengajaran dan Pembelajaran. Yogyakarta: Pustaka Pelajar.

Min, K.C., Rashid, A.M., \& Nazri, M.I. (2012). Teachers' Understanding and Practice towards Thematic Approach in Teaching Integrated Living Skills (ILS) in Malaysia. International Journal of Humanities and Social Science, 2(23), 273-281.

Nahdiyatin, Siti Nur. (2016). Penerapan Metode Make a Match untuk Meningkatkan Hasil Belajar IPS pada Siswa Kelas III SDN 1 Jenangan
Ponorogo. Gulawentah: Jurnal Studi Sosial, 1(2), 81-90.

Permendikbud No. 57 Tahun 2014 tentang Kurikulum 2013 Sekolah Dasar/Madrasah Ibtidaiyah.

Rusman. (2014). Model-model Pembelajaran Mengembangkan Profesionalisme Guru. Jakarta: Rajawali Pers.

Rusminawati, E.N. \& Mediatati, N. (2017). Penerapan Model Make a Match dalam Upaya Peningkatan Hasil Belajar IPS Siswa. Wacana Akademika, 1(2), 119 126.

Wibowo, K., \& Marzuki, M. (2015). Penerapan Model Make a Match Berbantuan Media untuk Meningkatan Motivasi dan Hasil Belajar IPS. Harmoni Sosial: Jurnal Pendidikan IPS, 2(2), 158169.

Yuliati. (2017). Penerapan Metode Pembelajaran Make a Match untuk Meningkatkan Hasil Belajar IPS Siswa Sekolah Dasar. Suara Guru: Jurnal Ilmu Pendidikan Sosial, Sains, dan Humaniora, 3(4), 723-730. 